\title{
JĘZYK ANGIELSKI I JĘZYK NIEMIECKI JAKO JĘZYKI PIVOT W CHIŃSKO-POLSKIM ORAZ POLSKO-CHIŃSKIM TŁUMACZENIU UMÓW NAJMU, DZIERŻAWY ORAZ LEASINGU
}

Zarys treści: Niniejszy artykuł ma na celu przybliżenie problematyki przekładu polsko-chińskich i chińsko-polskich umów najmu, dzierżawy, leasingu w oparciu o język niemiecki i język angielski jako języki pivot. W pierwszej części artykułu scharakteryzowano instytucję najmu, dzierżawy i leasingu oraz prawo własności. Następnie opisano metodę tłumaczeniową zaproponowaną przez Kierzkowską (2002). Zaprezentowane podstawowe czynniki determinujące język wspomnianych umów pokazały, że stosowanie języków pośrednich może wbrew intencjom tłumacza utrudnić poprawny przekład.

\section{Wstęp}

Drak znajomości terminologii chińskiego języka prawa oraz brak specjaliD stycznych słowników języka chińskiego i publikacji na temat języka prawa w Polsce powodują, że tłumacze lub adepci tłumaczenia języka chińskiego posługują się podczas przekładu tekstów z zakresu prawa językami pivot, czyli językami pośrednimi. Językiem pivot bywa zwykle język angielski lub - ze względu na podobieństwo systemów prawnych Niemiec i Chin - język niemiecki. Celem niniejszego artykułu jest przybliżenie problemów związanych z polsko-chińskim i chińsko-polskim przekładem umów najmu, dzierżawy i leasingu oraz z posługiwaniem się podczas tego tłumaczenia językami pośrednimi. 


\section{Podstawy prawne instytucji najmu, dzierżawy, leasingu}

W celu określenia zakresu naszych rozważań sprecyzujmy umowę naj$\mathrm{mu}$, dzierżawy i leasingu. Umowy te regulowane są przez prawo zobowiązań. Zgodnie z Kodeksem cywilnym zobowiązanie polega na tym, że wierzyciel może żądać od dłużnika świadczenia, a dłużnik powinien to świadczenie spełnić (art. 353 k.c.). Zobowiązanie jest stosunkiem prawnym, w którym występują dwie strony: podmiot uprawniony, określany wierzycielem, i podmiot zobowiązany, określany dłużnikiem, oraz przedmiot zobowiązania i jego treść. Niekiedy może się zdarzyć, że stronę stosunku zobowiązaniowego reprezentuje kilka podmiotów albo że w stosunku zobowiązaniowym pojawi się osoba trzecia. Treść zobowiązania obejmuje uprawnienia wierzyciela, czyli wierzytelności oraz obowiązki obciążające dłużnika, czyli dług (Radwański, 2005: 10-15). Umowy zobowiązujące podzielić można ze względu na ich funkcje w obrocie cywilnoprawnym. Umowy najmu, dzierżawy oraz leasingu dotyczą korzystania z rzeczy lub praw, dlatego ma do nich zastosowanie również prawo rzeczowe.

Przez umowę najmu wynajmujący zobowiązuje się oddać najemcy rzecz do używania przez czas oznaczony lub nieoznaczony, a najemca zobowiązuje się płacić wynajmującemu czynsz (art. 659 k.c.). Przedmiotem najmu mogą być tylko dobra materialne. Umowa musi określać przedmiot najmu oraz wysokość czynszu. Zwykle zawiera również informacje dotyczące okresu korzystania $\mathrm{z}$ przedmiotu najmu. Skutkiem zawarcia umowy najmu jest wydanie przez wynajmującego przedmiotu najmu najemcy oraz umożliwienie mu korzystania $z$ wynajętego przedmiotu. Wynajmujący powinien przez okres najmu utrzymywać rzecz w stanie zdatnym do umówionego użytku, co oznacza, że powinien on ponosić koszty za konieczne naprawy wynajmowanej rzeczy. Obowiązkiem najemcy jest należyte używanie najmowanego przedmiotu i sprawowanie nad nim pieczy oraz regularne uiszczanie czynszu. Po zakończeniu najmu najemca zobowiązany jest do zwrotu wynajmującemu przedmiotu najmu (Gniewek 2002: 485-487).

Korzystanie z rzeczy reguluje również umowa dzierżawy. Zgodnie z Kodeksem cywilnym przez umowę dzierżawy wydzierżawiający zobowiązuje się oddać rzecz do używania i pobierania pożytków przez czas oznaczony lub nieoznaczony, a dzierżawca zobowiązuje się płacić wydzierżawiającemu ustalony czynsz. Czynsz może być uiszczany w pieniądzach albo świadczeniach innego rodzaju, np. częścią pożytków z dzierżawionej rzeczy (art. 693 k.c.). Do dzierżawy stosuje się częściowo przepisy o najmie. Umowa dzierżawy powinna zawierać ustalenia dotyczące terminów uiszczania czynszu (art. 693-709 k.c.). 
Kolejną umową określającą korzystanie z rzeczy jest umowa leasingu. Zgodnie z Kodeksem cywilnym przez umowę leasingu „finansujący zobowiązuje się, w zakresie działalności swego przedsiębiorstwa, nabyć rzecz od oznaczonego zbywcy na warunkach określonych w tej umowie i oddać tę rzecz korzystającemu do używania albo używania i pobierania pożytków przez czas oznaczony, a korzystający zobowiązuje się zapłacić finansujące$\mathrm{mu} \mathrm{w}$ uzgodnionych ratach wynagrodzenie pieniężne, równe co najmniej cenie lub wynagrodzeniu z tytułu nabycia rzeczy przez finansującego" (art. 709 k.c.). Umowa leasingu do niedawna była umową nienazwaną i dopiero w 2000 r. uregulowano ją w Kodeksie cywilnym. Polski ustawodawca ustalił obcojęzyczną nazwę tej umowy, która przyjęła się w języku polskim z wymową angielską i pełną deklinacją polską. W umowie określa się zbywcę i nabywcę rzeczy, korzystającego z rzeczy, czas trwania stosunku leasingu oraz wysokość wynagrodzenia, które winien uiszczać korzystający z rzeczy (Gniewek 2002: 491-492).

\section{Metoda ttumaczeniowa}

Do tłumaczenia umów najmu, dzierżawy oraz leasingu z języka polskiego na język chiński i z języka chińskiego na język polski zastosowano model pragmatycznego tłumaczenia terminów prawnych Kierzkowskiej, zaprezentowany w książce pt. Tłumaczenia prawnicze (Kierzkowska 2002). Model ten oparty został na „zasadach szeroko pojętej teorii skoposu oraz sprawdzonej w praktyce metodologii pragmatycznego tłumaczenia tekstów prawnych i prawniczych (Kierzkowska 2002: 72). Warto przypomnieć, że teoria skoposu to teoria Vermeera, której założeniem jest przyporządkowanie celu wszelkiemu działaniu tłumacza. Oznacza to, że każdy tekst docelowy powinien być dostosowany do celu, czyli skoposu. Tłumacz powinien więc sobie zdawać sprawę z celu swojego działania. Zgodnie z teorią Kierzkowskiej wybór strategii tłumaczenia tekstu powinno poprzedzać określenie funkcji tekstu źródłowego oraz tekstu docelowego, a następnie określenie imperatywu odbiorcy i imperatywu uzusu terminologicznego. Wyróżnia się następujące rodzaje odbiorców (Kierzkowska 2002: 97-98):

- odbiorcę bliskiego,

- odbiorcę dalekiego,

- odbiorcę samookreślonego.

W przypadku języka źródłowego polskiego i języka docelowego chińskiego odbiorcą bliskim może być na przykład przedsiębiorca chiński działający 
w Polsce, któremu nie są obce realia i obyczaje naszego kraju. Odbiorcą dalekim może zostać określony przebywający w Polsce na stypendium naukowym chiński student medycyny, który pragnie mieć ogólne pojęcie na temat prawa w Polsce, np. z powodu dokonanego wykroczenia lub problemów, które przytrafily mu się w związku z wynajmowaniem mieszkania. Trzecim typem odbiorcy, czyli odbiorcą samookreślonym, może być polski lub chiński zleceniodawca tłumaczenia, który z góry określa swoje wymagania terminologiczne.

Kolejna z zalecanych przez Kierzkowską czynności mających poprzedzać tłumaczenie to stwierdzenie uzusu terminologicznego. Terminologia może być ustalona przez zleceniodawcę tłumaczenia i tworzyć w ten sposób uzus zleceniodawcy. Może być ona również ujednolicona i zebrana, tworząc tzw. uzus międzynarodowy. Jeszcze innym rodzajem uzusu terminologicznego może być uzus narodowy, polegający na stosowaniu narodowej terminologii preskryptywnej. Terminologia taka występuje $\mathrm{w}$ aktach prawodawczych poszczególnych państw. Może być również terminologią polskojęzyczną aktów danego prawa. W przypadku Polski doskonałym przykładem jest wspomniana przez Kierzkowską terminologia polskojęzyczna aktów prawa wspólnotowego. Ostatnim typem uzusu jest translacyjny uzus lokalny, który polega na stosowaniu na danym obszarze najbardziej popularnego dla danego pojęcia ekwiwalentu (Kierzkowska 2002: 91-94). Dopiero po określeniu odbiorcy i ewentualnego uzusu terminologicznego tłumacz powinien dokonać wyboru strategii, czyli zasady odpowiedniej ekwiwalencji.

\section{Porównanie rzeczywistości prawnych języka polskiego, chińskiego, niemieckiego i angielskiego}

Przed przystąieniem do wyboru strategii tłumaczenia, tłumacz powinien dokonać rozpoznania rzeczywistości prawnych języka źródłowego oraz docelowego (Sandrini 1996: 142). Systemy prawne pogrupowane są za pomocą wyróżniających je cech dotyczących pochodzenia, rozwoju, ideologii i instytucji prawnych w nazywane przez Sandriniego Rechtskreisen (Sandrini 1996: 153). Porównanie prawa w różnych państwach odbywa się w dwojaki sposób. Może to być porównanie typu makro lub porównanie typu mikro. W pierwszym przypadku porównujemy ogólnie systemy prawne i kultury prawa, a to pozwala nam $\mathrm{z}$ kolei na porównanie typu mikro, polegające na zestawieniu poszczególnych instytucji i norm prawnych oraz pozwalające na zapoznanie się z terminologią porównywanych systemów prawnych (Rheinstein 1987: 31). Ze względu 
na styl prawa, specyfikację rozwoju historycznego, sposób myślenia prawniczego, rodzaje instytucji prawnych, rodzaje źródeł prawa i ideologię prawa wyróżnia się następujące kultury prawne (Tokarczyk 2005: 103-110, 6-8):

- kulturę prawa stanowionego,

- kulturę common law,

- kulturę prawną judaizmu,

- kulturę prawną chrześcijańska,

- kulturę prawa europejskiego,

- kulturę prawną islamu,

- kultura prawną hinduizmu,

- kultura prawną buddyzmu,

- kultura prawną konfucjanizmu,

- kultura prawną animizmu.

Już pobieżny przegląd kultur prawnych języka polskiego, chińskiego oraz zastosowanych w tłumaczeniu języków pivot pozwala nam stwierdzić, że języki te należą do zupełnie różnych kultur prawnych, a więc różnią się od siebie pod wieloma względami. Język chiński można śmiało przypisać do kultury prawnej konfucjanizmu oraz kultury prawnej buddyzmu. Język angielski należy do grupy języków kultury common law, a język polski i niemiecki do kultury prawa stanowionego. Używając więc języka angielskiego jako pośredniego w tłumaczeniu chińskiej umowy najmu, tłumacz uwikłany jest w trzy różne kultury prawne, $\mathrm{z}$ czego niestety nie zawsze zdaje sobie sprawę. Jak się okazuje, nawet tłumacze prawa obowiązującego w Hongkongu mają problemy z przetłumaczeniem niektórych terminów z zakresu prawa $\mathrm{z}$ języka angielskiego na język chiński (Sarcevic 2000: 14). Świadomość przynależności języka do danej kultury prawnej może ułatwić tłumaczenie, natomiast brak takiej świadomości może prowadzić do popełnienia poważnych błędów tłumaczeniowych.

Wielu adeptów sztuki tłumaczenia uważa, że w Wielkiej Brytanii i Stanach Zjednoczonych stosuje się jedynie prawo znane jako common law. Anglia faktycznie nie stosuje prawa stanowionego w formie ogólnych kodyfikacji całych dziedzin prawa, które odpowiadałyby występującemu w większości Europy podziałowi prawa na cywilne, karne, administracyjne itd. W rzeczywistości jednak w Anglii występuje dwuwarstwowość prawa, bo oprócz common law sądy stosują equity, łagodzące wyroki wydane na podstawie ustanowionych precedensów. Źródłem prawotwórczym jest też coraz częściej ustawa (Matulewska 2005: 63-64). Prawo polskie i prawo niemieckie oparte są na prawie rzymskim i wiele instytucji do dziś funkcjonujących ma swoje korzenie właśnie w nim. Prawo stanowione w tych dwóch 
krajach obejmuje konstytucję, ustawy, ratyfikowane umowy międzynarodowe, rozporządzenia oraz akty prawa miejscowego. Ponadto w krajach tych mamy do czynienia $\mathrm{z}$ prawem skodyfikowanym w formie kodeksów. Polski Kodeks cywilny dzieli się na cztery księgi, co związane jest z uznanym przez większość systemów prawnych opartych na prawie rzymskim tzw. systemem pandektowym, opracowanym przez naukę niemiecką i stosowanym od XIX w. Wyróżniamy cztery działy prawa cywilnego: prawo rzeczowe, prawo zobowiązań, prawo rodzinne i prawo spadkowe (Radwański 2002: 15-16). Z kolei podstawowe źródła prawa cywilnego w Chinach to obowiązująca od 1987 r. konstytucja 中华人民共和国民法通则 Zhōnghuá Rénmín Gònghéguó mínfă tōngzé (Ogólne reguły prawa cywilnego) oraz najróżniejsze ustawy uzupełniające wymienione źródła. Dokumenty te określają prawa i obowiązki obywateli Chińskiej Republiki Ludowej. Wyróżnia się prawa osobowe, prawa własności intelektualnej, prawa majątkowe oraz prawo zobowiązań. Ostatnie dwa regulują omawiane przez nas najem oraz leasing (Harro von Senger, 131-132). Chińskie prawo cywilne wzorowane jest na prawie niemieckim, a część dotycząca spółek - na prawie handlowym Stanów Zjednoczonych.

\section{Różnice w prawie własności w Polsce, Niemczech, Wielkiej Brytanii, USA i Chinach}

Omawiane w niniejszym artykule umowy najmu, dzierżawy i leasingu dotyczą korzystania z rzeczy lub praw. Instytucja własności stanowi prawną formę korzystania z rzeczy. W Polsce podstawą ustroju jest własność prywatna, obejmująca wszystko, co może należeć do osoby fizycznej lub prawnej. Wyróżnia się również własność społeczną, czyli publiczną, która obejmuje własność Skarbu Państwa i innych państwowych osób prawnych, własność jednostek samorządu terytorialnego (czyli gmin, powiatów, województw) i własności organizacji społecznych (Gniewek 2002: 180-185). Uprawnienie do posiadania rzeczy jest jednocześnie uprawnieniem do władania tą rzeczą. Zgodnie z Kodeksem cywilnym rzeczami są tylko przedmioty materialne. Nieruchomościami są części powierzchni ziemskiej stanowiące odrębny przedmiot własności (grunty) jak również budynki trwale z gruntem związane lub części takich budynków, jeżeli na mocy przepisów szczególnych stanowią odrębny od gruntu przedmiot własności. Nieruchomościami rolnymi są nieruchomości, które są lub mogą być wykorzystywane do prowadzenia 
działalności wytwórczej w rolnictwie w zakresie produkcji roślinnej i zwierzęcej, nie wyłączając produkcji ogrodniczej, sadowniczej i rybnej. Budynki i inne urządzenia trwale $z$ gruntem związane, jak również drzewa i inne rośliny od chwili zasadzenia lub zasiania stanowią części składowe nieruchomości.

W Niemczech podobnie jak w Polsce obowiązuje przede wszystkim własność prywatna, a prawo rzeczowe reguluje prawo własności oraz sposoby przenoszenia tego prawa.

Trochę inaczej wygląda sytuacja własności w systemie brytyjskim, gdzie majątek jest określany jako property i definiowany jako anything that can be owned (Oxford 2003: 389). Jak opisuje Matulewska, brytyjskie property dzieli się na następujące rodzaje majątku:

- real property, czyli grunt i tzw. incorporeal hereditaments, tzn. takie składniki majątku, które można dziedziczyć i które są prawami rzeczowymi, takimi jak służebności gruntowe czy też pożytki określane nazwą profits à prendre (Oxford 2003: 230),

- personal property nazywane też personalty czyli majątek z wyłączeniem gruntu i incorporeal hereditaments.

W systemie amerykańskim w niektórych stanach obowiązuje podział majątku przedstawiony powyżej, $\mathrm{w}$ innych stosuje się równolegle podział property na (Matulewska 2005: 63-64):

- land, czyli grunt,

- immovable, czyli wszytko co na trwałe z tym gruntem jest związane,

- movable, czyli wszystko co można dotknąć i przenieść.

W Chinach nie ma, jak to jest w Polsce i w Niemczech, odrębnej księgi w kodeksie, która reguluje prawo rzeczowe. Zastępują ją różne ustawy. Zobowiązania dotyczące praw własności powstają m.in. poprzez zawieranie umów. Chińskie prawo własności stanowi, że właścicielem praw majątkowych może być zarówno państwo, jak i jego obywatele. Do niedawna jednak tylko państwowe prawa majątkowe chronione były przez prawo. Do prywatnych praw majątkowych obywateli zalicza się m.in. legalne zarobki, domy, oszczędności, przedmioty codziennego użytku, książki, pisma, bydło i środki produkcji. Obywatele mogą również zagospodarowywać należące do państwa lasy, góry, łąki i powierzchnie wodne. $\mathrm{W}$ ramach określonych przez ustawy mogą oni też wykorzystywać bogactwa naturalne (Chiński kodeks prawa cywilnego 1986: art. 71-81, tłum. J. G.). Różnicę stanowi niewątpliwie prawo własności gruntów. Rolnicy mają prawo do prywatnego użytkowania (自留地 ziliúdi) ziemi rolnej. Niestety, w praktyce często bywają wywłaszczani. Ziemia w miastach stanowi własność państwową. Żadna or- 
ganizacja ani żaden obywatel nie może rozporządzać prawem własności ziemi. Warto zwrócić uwagę na fakt, że w Chińskiej Republice Ludowej do 2004 r. nie wyróżniano własności prywatnej. Pojęcie to było zwykle pomijane. Używało się słów posiadanie, własność, ale bez mówienia o prywatności. Istniała wyłącznie własność publiczna. O własności prywatnej wspominano tylko w prawie spadkowym i rodzinnym. Do niedawna tylko państwowe prawa majątkowe były chronione przez prawo. Dopiero w marcu $2007 \mathrm{r}$. w Chinach przyjęto ustawę o ochronie własności prywatnej. Zakres nowego prawa jest jednak ograniczony, bo nie dotyczy wsi, na której mieszka nadal ponad połowa społeczeństwa chińskiego. Ziemia pozostaje własnością państwa, chłopi mają jedynie długoletnie prawo jej użytkowania. Niestety, często bywa tak, że wszechmocni lokalni urzędnicy wywłaszczają chłopów pod budowę fabryk i osiedli.

Powyższy, pobieżny opis prawa własności w Polsce, Chinach, Niemczech, Wielkiej Brytanii i USA pozwala nam zauważyć, że stosowany w tłumaczeniu język niemiecki i język angielski nie tylko nie zawsze mogą być pomocne, ale nawet mogą stanowić utrudnienie w prawidłowym rozumieniu poszczególnych terminów z zakresu prawa własności i prawa zobowiązań. Jak się okazuje, tłumacz powinien nie tylko orientować się w tym, co jest źródłem prawa $\mathrm{w}$ danym kraju, ale powinien również wiedzieć, co faktycznie i przede wszystkim to prawo kształtuje.

I tak w prawie kontynentalnym pierszeństwo mają ustawy, a w common law - tradycje, zwyczaje, precedensy, statute law (Sandrini 1996: 162-163). Jeżeli weźmiemy pod uwagę Chiny już pobieżna orientacja pozwoli nam stwierdzieć, że o kształcie i implementacji prawa decydują często nie prawnicy, ale politycy. Wszechmocni urzędnicy wywłaszczają chłopów wbrew powszechnym poglądom na temat istnienia własności prywatnej i praw człowieka w tym kraju. Warto wspomnieć tu o zaleceniu Sandriniego, który wspomina o konieczności zwrócenia uwagi na tzw. law in action, czyli zależności prawa i środowiska, w jakim ono funkcjonuje (Sandrini 1996: 164). Okazuje się więc, że w celu dobrego przetłumaczenia tekstu z zakresu prawa potrzebna jest nie tylko znajomość systemu prawa języka źródłowego, docelowego i pośredniego, ale również wiedza na temat aktualnej sytuacji socjologicznej, politycznej w danym państwie. Dotyczy to szczególnie Chin, gdzie postępujący w oszałamiającym tempie rozwój gospodarczy powoduje, że z komunizmu zostaje tylko fasada, a w rzeczywistości mamy już do czynienia $\mathrm{z}$ kapitalizmem. Należy mieć świadomość, że zmiany te niewątpliwie wpłyną na język prawa. 


\section{Inne problemy przekładu za pomocą języków pośrednich}

Oprócz różnic w rzeczywistościach prawnych tłumaczonego przez nas języka źródłowego, docelowego i języków pivot warto wymienić inne trudności, jakie nastręcza posługiwanie się językami pośrednimi. Tłumacząc język polski na język chiński i odwrotnie można się czasem posłużyć słownikami niemiecko-chińskimi bądź angielsko-chińskimi. Należy sobie jednak zdawać sprawę z faktu, że pojęcia języka pośredniego mogą nieznacznie odbiegać od zakresu pojęciowego tłumaczonego języka źródłowego oraz języka docelowego. Ważne jest zatem dokładne zanalizowanie znaczenia pozornie znanego nam pojęcia w języku pivot. W tym celu warto ustalić rodzaj ekwiwalencji pomiędzy danymi terminami. Jak zaznacza Arntz, niektóre pary językowe danych pojęć pokrywają się w pełni pod względem zakresu znaczenia, a niektóre całkowicie się od siebie różnią. Bywa też tak, że mamy do czynienia z tzw. inkluzją, kiedy pojęcie w języku A ma te same cechy, co pojęcie w języku B, ale jego definicja ma cechy dodatkowe. Pojęcie $\mathrm{z}$ języka B zawiera się wówczas w pojęciu w języku A (Arntz, Picht 1991: 160).

Kolejnym problemem stosowania języków pośrednich w tłumaczeniu jest w przypadku umów najmu, dzierżawy i leasingu obecność polisemii i homonimii w terminologii tych umów. Sytuację tę ilustrują przykłady ukazane w poniższych tabelach:

\section{Najem}

\begin{tabular}{|l|l|l|l|}
\hline \multicolumn{1}{|c|}{ Polska } & \multicolumn{1}{|c|}{ Niemcy } & \multicolumn{1}{c|}{ Wielka Brytania/USA } & \multicolumn{1}{c|}{ Chiny } \\
\hline najmować & mieten & to lease & 租用 zūyòng \\
\hline najem & Miete & lease/tenancy & 租赁 zūlìn \\
\hline wynajmować & vermieten & to lease & 出租 chūzū \\
\hline wynajmujący & Vermieter & lessor/landlord & 出租人 chūzūrén \\
\hline najemca & Mieter & lessee/leaseholder/tenant & 承租人 chéngzūrén \\
\hline czynsz & Miete & rental fee & 租金 zūjīn \\
\hline podnajem & Untermiete & sublease & 转租 zhuănzū \\
\hline
\end{tabular}




\section{Dzierżawa}

\begin{tabular}{|l|l|l|l|}
\hline \multicolumn{1}{|c|}{ Polska } & \multicolumn{1}{|c|}{ Niemcy } & \multicolumn{1}{c|}{ Wielka Brytania/USA } & \multicolumn{1}{c|}{ Chiny } \\
\hline dzierżawa & Pacht & lease & 租赁 zūlìn \\
\hline wydzierżawiający & Verpächter/-in & lessor, landlord & 出租人 chūzūrén \\
\hline dzierżawiący & Pächter/-in & lessee, leaseholder, tenant & 租用者 zūyòngzhĕ \\
\hline czynsz & Pachtzins & rental fee & 租金 zūjīn \\
\hline dzierżawić & pachten & to lease & 租用 zūyòng \\
\hline poddzierżawa & Unterpacht & sublease & 转租 zhuănzū \\
\hline
\end{tabular}

\section{Leasing}

\begin{tabular}{|l|l|l|l|}
\hline \multicolumn{1}{|c|}{ Polska } & \multicolumn{1}{|c|}{ Niemcy } & Wielka Brytania/USA & \multicolumn{1}{c|}{ Chiny } \\
\hline leasing & Leasing & lease & 融资租赁 róngzī zūlìn \\
\hline leasingodawca & Leasinggeber & lessor & 出租人 chūzūrén \\
\hline $\begin{array}{l}\text { leasingobiorca, } \\
\text { biorący w leasing }\end{array}$ & Leasingnehmer & lessee & 承租人 chéngzūrén \\
\hline
\end{tabular}

Jak możemy zaobserwować, język angielski, funkcjonujący w naszym tłumaczeniu jako język pośredni, oraz język chiński, będący na przykład językiem źródłowym, nie rozróżniają w swojej terminologii dzierżawy od najmu. Nie sposób też znaleźć różnicy między dającym w leasing, wynajmującym i wydzierżawiającym, itd. Okazuje się, że odpowiednie tłumaczenie terminów dotyczących umowy najmu, dzierżawy, leasingu w tych językach na język polski lub niemiecki możliwe jest jedynie w oparciu o szeroki kontekst dokumentu.

\section{Zakończenie}

Język polski, niemiecki, angielski i chiński to języki różnych systemów prawnych. Zdaniem Šarčević integralną cechą terminologii różnych systemów prawnych jest ich nieprzystawalność (Šarčević 1997: 235, cyt. za: Kierzkow- 
ska 2002: 59). Dlatego stosowanie języków pivot może często okazać się nie ułatwieniem, ale utrudnieniem w poszukiwaniu odpowiedniego ekwiwalentu dla danego terminu z zakresu prawa. Konieczność odróżniania systemów prawnych przy tłumaczeniu tekstów z zakresu prawa akcentowali w wypowiedziach m.in. Kierzkowska, Rayar, Sandrini (Kierzkowska 2002: 62). R. Stolze (1999: 170), podkreślając różnorodność źródeł języka prawa, proponuje zastosowanie zasady „wspólnego minimum”. Wspólnym minimum może być na przykład pojęcie bardziej ogólne, które zawiera znaczenie pojęcia w języku docelowym oraz pojęcie w języka źródłowego, dla którego trudno znaleźć odpowiedni ekwiwalent. Niestety, okazuje się, że wspólne minimum może stanowić poważny problem $\mathrm{w}$ komunikacji między przedsiębiorcą chińskim a przedsiębiorcą polskim, który nie zawsze zdaje sobie sprawę z faktu, że grunty w Chinach stanowią własność państwową i nabycie własności danego budynku nie wiąże się z nabyciem własności gruntu, na terenie którego ten budynek stoi.

Jak twierdzi Kierzkowska, obowiązkiem każdego tłumacza jest osiągnięcie ekwiwalencji tekstowo-normatywnej w tłumaczeniu tekstów z zakresu prawa. Oznacza to, że powinien on stosować normy językowe i tekstowe właściwe dla danego tekstu i zgodne z językową tradycją (2002: 96). Tłumacz języka chińskiego powinien więc wzorować się na tekstach paralelnych i nie kierować się formami tłumaczenia przepisów prawnych na język niemiecki lub angielski. Każdy z tych języków ma bowiem własną konwencję formułowania przepisów prawnych, utarte formy i stylistykę.

Cechy pojęć z zakresu języka prawa odpowiadają ściśle cechom danego prawnego stanu faktycznego (Sandrini 1996: 30). Dlatego też czasem pozornie identyczne znaczeniowo pojęcia $\mathrm{z}$ różnych języków różnią się tak naprawdę zakresem ekwiwalentów znaczeniowych w rzeczywistościach prawnych, do których przynależą. W celu poznania zakresu danego pojęcia warto sprawdzić jego definicje w interesujących nas językach. Co ważne definicje pojęć prawnych są ograniczone czasowo, obowiązują jedynie na określonym obszarze i mogą zostać w każdym momencie zmienione, np. poprzez poszerzenie znaczenia (Sandrini 1996: 54). Dobrym przykładem potwierdzającym tą tezę może być definicja własności prywatnej w Kraju Środka. Jak wspomniano wyżej, ochrona własności prywatnej została ustanowiona dopiero w marcu 2007 roku.

W obliczu wymienionych w powyższym artykule czynników wpływających na źródłowy i docelowy język prawa, należy zastanowić się nad sensem posługiwania się w tłumaczeniu językami pośrednimi. 


\section{Literatura}

Arntz, R., Picht, H., 1991, Einführung in die Terminologiearbeit, Hildesheim. Bürgerliches Gesetzbuch, 2006.

Gniewek, E., 2002, Podstawy prawa cywilnego i handlowego, tom I, Wrocław. Hanyu falü cidian, 1999, Beijing.

Jones, C. W., 1989, Basic Principles of Civil Law in China, New York.

Kierzkowska, D., 2002, Ttumaczenie prawnicze, Warszawa.

Koebler, G., 2002, Rechtschinesisch. Deutsch-chinesisches und chinesisch-deutsches Rechtswörterbuch für jedermann, München.

Li Mingzheng, „An Introduction to the Provisions on Financial Leasing Contracts in the Contract Law of China", [w:] Comparative Analysis on the Chinese Contract Law, Gebhardt, I., Zhang Yuqing, Schröder, R. (red.), Berlin, s. 333-348.

Radwański, Z., 2002, Prawo cywilne - część ogólna, Warszawa.

Radwański, Z., 2005, Zobowiązania - część ogólna, Warszawa.

Rheinstein, M., 1987, Einführung in die Rechtsvergleichung, München.

Sandrini, P., 1996, Terminologiearbeit im Recht. Deskriptiver begriffsorientierter Ansatz vom Standpunkt des Übersetzers, Vienna.

Sarcevic, S., 2000, New Approach to Legal Translation, The Hague.

Schröder, R., 2003, „Landlord and Tenant Law in the Federal Republic of Germany in Comparision to the Landlord and Tenant Law of the People's Republic of China", [w:] Comparative Analysis on the Chinese Contract Law, Gebhardt, I., Zhang Yuqing, Schröder, R. (red.), Berlin, s. 315-331.

Senger, H. von, 1994, Einführung in das chinesische Recht, München.

Stolze, R., 1999, Die Fachübersetzung, Tübingen.

Tokarczyk, R., 2005, Współczesne kultury prawne, Kraków.

Wegmann, K., 2005, Rechtsdenken. Schnittpunkte West und Ost. Recht in den gesellschafts- und staatstragenden Institutionen Europas und Chinas, Münster.

Yinhan Falü Cidian, 1998, Beijing.

Zhonghua Renming Gongheguo Mingfa, 1999, Beijing.

\section{Webografia}

Matulewska, A., 2005, „Własność i zobowiązania w aspekcie translatorycznym polsko-angielskim i angielsko-polskim", [w:] Investigationes Linguisticae, t. XII, s. 62-76. 
http://www.staff.amu.edu.pl/ inveling/index.php?page=issues\&vol=12\&cat $=0 \&$ article $=72$.

http://www.handelsblatt.com/news/_pv/_p/200051/_t/ft/_b/1236012/default.aspx/index.html (dostęp: 08.03.2007).

http://www.ftd.de/politik/international/174314.html?nv=cd-topnews, (dostęp 16.03.2007).

\section{English and German as pivot languages in Chinese-Polish and Polish-Chinese translation of contracts of lease \\ (summary)}

This article gives short characteristics of the main problems of Chinese-Polish and Polish-Chinese translation of the different types of lease contracts. The translation was done by using pivot languages: German and English. The language and vocabulary used in Chinese, Polish, German and English lease contracts are researched into. Then, the translation strategy suggested by Kierzkowska (2002) is discussed. The author shows the problem of influence of culture on legal systems and languages of the law in general. Basic differences between property law in Poland, China, Germany, England and USA are analysed. Linguistic features and culture background that characterize legal language in China, Germany, Great Britain, USA and Poland differ significantly. Many rules and practices of foreign law can only be understood by applying legal thinking, cultural archetypes, history and common linguistics patterns of foreigners. The author also shows differences in the meaning of terms, which apparently signify the same entities and concepts in Polish and Chinese legal languages but, in fact, differ significantly. The author gives examples of other sources of ambiguity in translation of Polish and Chinese lease contracts and focuses on polysemy and homonymy which make the interpretation of legal language difficult and ambiguous. The meaning of Chinese characters depends on the textual context. However, when the translator does not know the background information of translated legal texts, it is very difficult to achieve high quality legal translation. Finally, the author shows that the translation of Chinese and Polish contracts by using German and English can be more difficult, problematic and incorrect due to differences between pivot languages, source language and target language. 